\title{
TOWARDS A STRATEGIC APPROACH TO RESEARCH AND INNOVATION FOR FOOD SYSTEMS TRANSFORMATION IN CENTRAL AND EASTERN EUROPE
}

\begin{abstract}
Pawel CHMIELIŃSKI, Institute of Rural and Agricultural Development Polish Academy of Sciences, Nowy Świat 72, Warsaw, Poland and European Rural Development Network, Owocowa 8, Milanówek, Poland, pchmielinski@irwirpan.waw.pl

The transformation of food systems is one of the greatest challenges in responding to the challenges facing supply chains and rural economies in European countries. It is also one of the key elements of the European Green Deal and the associated Farm to Fork strategy. The aim of this article is to present the results of a study identifying strategic areas of research and innovation that can contribute to a successful transition towards sustainable food systems. The results of the work of an international team, representing Central-Eastern European Countries (CEECs) and the scientific and administrative sector, indicate the need for fundamental changes on the production side, supply chain, research infrastructure and on the side of society (consumers), the synergy of which will form the basis for the transformation of food systems towards sustainability.
\end{abstract}

Keywords: sustainable food systems, research policy, innovation, CEEC, BIOEAST.

\section{INTRODUCTION}

The transformation of food systems is an approach that underpins sustainable development and responds to the challenges of the resilience of the rural economy, climate change and need for production shift (de Vries, 2021).

Sustainable food systems start with the development of sustainable agricultural practices, the development of more sustainable food distribution systems, the creation of sustainable diets and the reduction of food waste throughout the system. Sustainable food systems are at the centre of policy programmes focused on sustainability, such as the European Commission's proposed European Green Deal (Sonnino et al., 2020).

Food systems (FS) encompass the entire range of actors and their interlinked value-adding activities involved in the production, aggregation, processing, distribution, consumption and disposal of food products that originate from agriculture, forestry or fisheries, and parts of the broader economic, societal and natural environments in which they are embedded (FAO, 2018). The food system is composed of sub-systems (e.g. farming system, waste management system, input supply system, etc.) and interacts with other key systems (e.g. energy system, trade system, health system, etc.).

A sustainable food system (SFS) is a food system that delivers food security and nutrition for all in such a way that the economic, social and environmental bases to generate food security and nutrition for future generations are not compromised.

The American Public Health Association (APHA, 2007) defines a sustainable food system as one that provides healthy food to meet current nutritional needs while maintaining healthy ecosystems that can also provide food for future generations with minimal negative environmental impacts. A sustainable food system supports local food production and distribution infrastructure and makes food available and affordable for all. It is also humane and just, protecting farmers and other workers, consumers and communities.

The European Union (EC, 2020) defines a sustainable food system as one that provides and promotes safe, nutritious and healthy food with low environmental impact for all current and future EU citizens, in a manner that protects the environment and its ecosystem services, is robust and resilient, economically dynamic, equitable and socially acceptable (de Vries, 2021). It does so without compromising the availability of nutritious and healthy food for people living outside the EU or harming their environment.

Standing Committee on Agriculture Research Strategic Working Group on Food Systems (Niels \& Henk, 2019; SCAR, 2018) has signalled that food systems are of particular interest in MS research policies. Currently, the EU and global food systems are affected by major challenges such as climate change, its migration, a growing world population, urbanisation and resource scarcity, in addition to the "triple burden" of malnutrition (undernutrition, obesity, and hidden hunger), ageing and food poverty. Research and innovation is key to developing high-impact solutions to future-proof our food systems. There is a need for policy narrative advocating a complex approach to research and innovation on food systems and connecting producers and consumers, engaging a wide diversity of actors to build innovative and integrated value chains concerning sustainable farming systems, environmental challenges and human health.

Copyright (C) 2021 The Authors. Published by Vytautas Magnus University. This is an open-access article distributed under the terms of the Creative Commons Attribution License (CC BY 4.0), which permits unrestricted use, distribution, and reproduction in any medium, provided the original author and source are credited. 
The aim of this article is to present the results of a study identifying strategic areas of research and innovation that can contribute to a successful transition towards sustainable food systems. The paper presents the results of a group of experts and researchers from Central and Eastern European countries working together to identify challenges and research needs common to countries in this part of Europe. Through this work, research topics were developed that can be considered as priorities for future research on the transformation of food systems towards sustainability. It is an activity that is intended to support CEE countries in the correct identification of research needs and strategic approaches, but also to guide the intensification and targeting of EU R\&D support according to the needs of the 11 countries that this study represents.

\section{RESEARCH METHODS}

Presented material is based on the results of the Visegrad Group's and Central Eastern EU countries" ${ }^{1}$ cooperation in supporting analyses related to the development of bioeconomy development strategies under the BIOEAST initiative, that has been established in 2016 (Juhász \& Vásáry, 2017; Vásáry, 2019). The founders of the Initiative are the Ministers of Agriculture of the Visegrad Group countries.

The methodology of research applied in the study is based on participatory action research philosophy often applied in social sciences (Bergold \& Thomas, 2012; Sautier et al., 2017). It is a reflexive process, where the next step is conducted after a critical analysis of both results and process leading to these results. This approach also helps to bridge the gap between theory and practice (Moote et al., 1997).

The approach to determine the research challenges and needs, and the main source of data for this study included round tables and focus groups organised by the Thematic Working Group on Food Systems under the BIOEAST initiative (Chmieliński et al., 2021; Horváth, 2019), with the participation of the representatives of ministries of agriculture of 11 CEEC countries, and research institutes (Figure 1) under the H2020 BIOEASTsUP project ${ }^{2}$.

The topics proposed by the group members were discussed, aggregated and debated in a workshop in 2018. The list of strategic areas and topics ofwere discussed during 2 conferences with active participation of scientists and practitioners as well as representatives of the Ministries of Agriculture of 11 CEEC countries and representatives of EU agencies (Chmieliński et al., 2021). The overall research and consultation process lasted from 2019 to 2021 and was attended by more than 400 people.

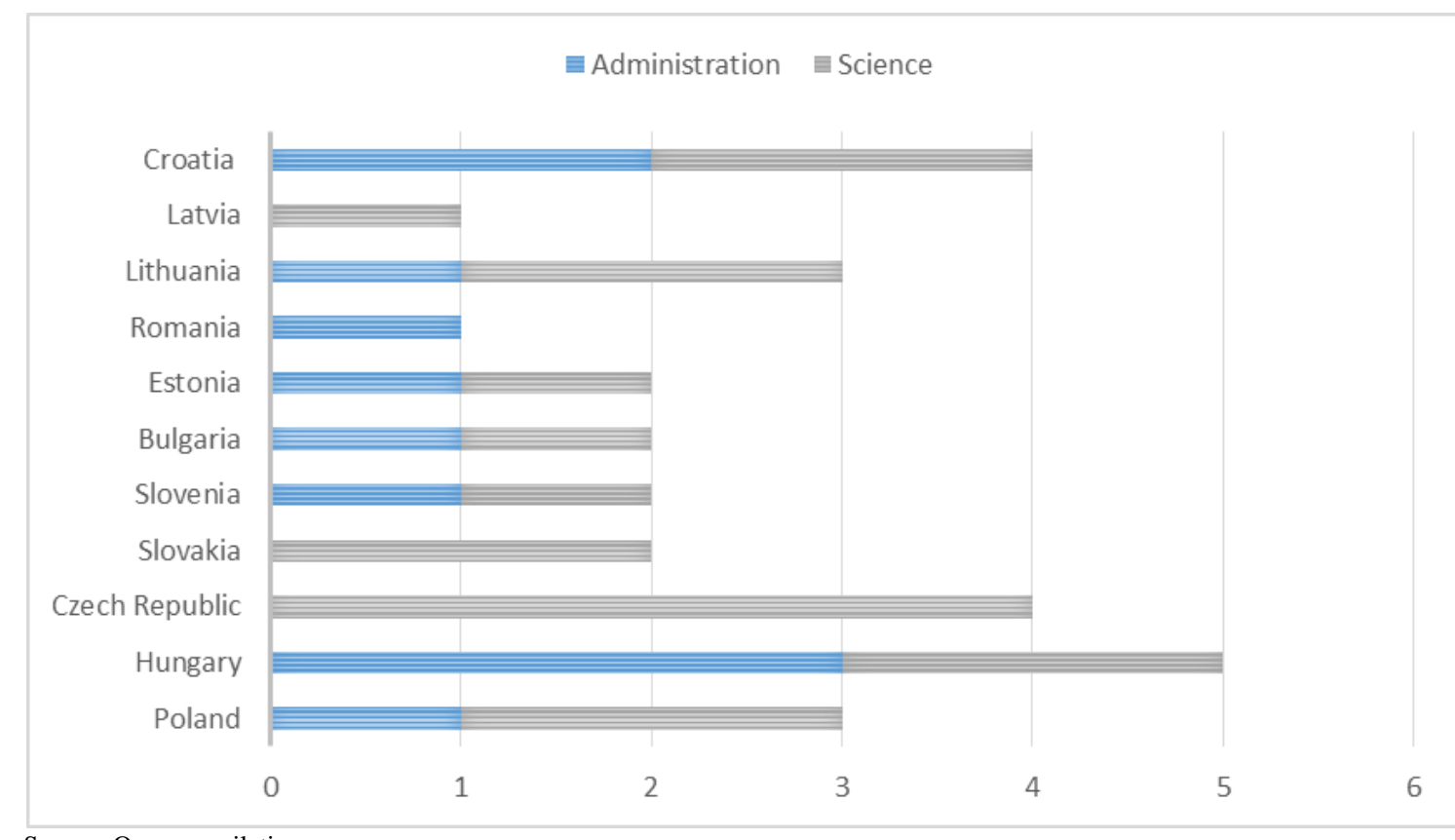

Source: Own compilation.

Figure 1. The composition of the BIOEAST Thematic Working Group on Food Systems according to the number, sector and country

The application of the participatory method to the countries of our region not only allows for a better identification of the problems and challenges facing food systems in the future, but also makes it possible to relate these problems to other research conducted at EU level. Such work results in the inclusion of the most pressing problems in EU research programmes, and this approach was guaranteed by the focus group interview method which was attended by 29 members of the group. the results of the research were presented and discussed at a workshop, in 2021 (Chmieliński et al., 2021),

\footnotetext{
${ }^{1}$ the Initiative encompasses 11 countries: Poland, Hungary, Slovakia, Czech Republic, Estonia, Lithuania, Latvia, Bulgaria, Croatia, Romania, Slovenia, cooperating in the area of strategic approach in R\&I for agriculture and bioeconomy development (www.bioeast.eu).

${ }^{2}$ Project "Advancing Sustainable Circular Bioeconomy in Central and Eastern European Countries" is a project funded through the European Research and Innovation programme, Horizon 2020, for the duration of three years (October 2019 to September 2022), see: https://bioeast.eu/bioeastsup/
} 
which was attended by 109 people. The results were also reviewed in a special session dedicated to food systems development at an online meeting in September 2021.

The supplementary methods of analysis, report and public statistics data, literature studiesand expert meetings were conducted in 2019-2021 (including those carried out within the framework of the BIOEAStsUP project) to support the cooperation of scientists and administrative representatives within the framework of the Food Systems Thematic Group of the BIOEAST initiative.

\section{RESEARCH RESULTS}

\section{Food Systems and the Sustainability - an overview and CEECs context}

Food Systems development is a key element of the European Green Deal and its new "Farm to Fork strategy", aiming to accelerate the transition towards more sustainable and socially just ways of producing, consuming and trading, while preserving and restoring our ecosystems. It also is in the heart of the successful implementation of the UN Sustainable Development Goals (SDGs) and Food System R\&I Policy implementation at the level of the European Commission (Galli et al., 2018).

Food systems play a key role in bioeconomy and therefore require the strategic advice and support, as it is stressed in the Policy Framework "FOOD 2030" and the EU Bioeconomy Strategy (Giuntoli et al., 2020). It should be stressed that cooperation within the European Research Area, and involvement in the Cluster 6 of Horizon Europe initiatives, as well as the European Partnerships, are extremely important tools for achieving the common objectives of creating added value in food systems (SCAR, 2018).

The strategic directions of food systems development in CEECs, discussed by an international team of experts and scientists from 11 countries, are based on the assumption that in the future they will constitute a fundamental basis for changing the whole economy, with particular emphasis on sectors based on the use of biomass, a renewable raw material. The main purpose of sustainable food system is nutritional food production with the respect to the environment and climate. One important element in this process is response to society needs to ensure that quality and quantity of food make the solid basis of food security. In this context, the challenges are focused around issues related to demographic structure, nutritious food delivery issues, and ensuring high levels of food safety and traceability. This includes also the problem of obesity, hunger and malnutrition reduction, thus helping consumers adopt sustainable and healthy diets to reduce the incidence of non-communicable diet-related diseases (Kneafsey et al., 2013; Potori et al., 2014).

In this context, research and innovation should take into account the activities to improve society awareness and practices (scientific evidence and knowledge from a wide diversity of actors) concerning inter alia more sustainable and healthy diets. It is also important to support different innovation implementation (boosting innovation and investment, new business models creation) establishment of governance models enabling sustainable and inclusive bioeconomy patterns, including consumption patterns, market measures and financial models (Bojnec \& Fertö, 2009; Lang, 2003). The foundation of the transformation process is the empowerment of communities and institutions (through closer partnerships with industry and food producers, markets that function in a responsible manner thereby fostering fair trade and pricing, inclusiveness and sustainability).

The second element generally influencing positive changes within food systems are natural environment protection and climate change mitigation. Challenges related to environmental issues are mainly stopping natural resources reduction, natural resources conservation and use within the planetary boundaries, as well as building climate smart food systems, while maintaining the biodiverse ecosystems (Wrzaszcz et al., 2015).

Action on food systems includes the need to map the interactions between the different components of current food systems, such as the interactions between food, biodiversity and water systems, to maximise co-benefits, accelerate transition and to better mitigate the climate change. This includes pointing to the need for a solid R\&I background to build climate smart and environmentally sustainable food systems adaptive to climate change, which conserve natural resources, and implement resource-efficient circular economy principles, while reducing environmental footprint (Zegar, 2021).

This also requires the provision of resilience and sustainable biomass production systems while ensuring the functions of balanced ecosystems with greater carbon sequestration and biodiversity conservation (Chmieliński, 2021; Niels \& Henk, 2019).

Finally, the third general element in understanding the sustainability of food systems is understanding of complex adaptive food systems at different levels and ensuring the multi-level approach to food chains analysis (El Bilali, 2019). The main challenge is to ensure diversity in food systems (production, processing, packaging, logistics, distribution, consumer), better organisation of short chains, to improve agricultural practices (production diversity, sustainable production, precise practices) as well as circular solutions and waste management (reducing environmental footprint, food losses, resource-efficient solution implementation) (Bojnec \& Fertő, 2015; Potori et al., 2014).

\section{Four Strategic areas of the research and innovation for the sustainable food systems transformation in CEECs}

Using participatory techniques (roundtables, focus groups, interviews), a broad catalogue of issues was narrowed down to the main four strategic axes around which policies can be developed, partners mobilised and the transformation of food systems in CEECs supported (Figure 1).

A bottom-up stakeholder driven approach for defining synergies and complementarities between the agricultural sectors of CEE and the main challenges for food system research and innovation are defined in relation to four main areas related to sustainable food production, food chains, research infrastructure and consumer awareness (Chmieliński et al., 2021). 
In particular, the four main areas identified by the participants in the study, which constitute the strategic areas of the research and innovation for the sustainable food systems transformation in CEECs in the future, are presented below. Each of them contains a number of specific issues, the scope of which is discussed below. At the same time, each of the analysed areas is strongly supported by the literature, hence the empirical analysis has been enriched with references to studies that essentially support it. In this way, the practical exercise from which the set of development kirks needed was derived and identified was supported by evidence.

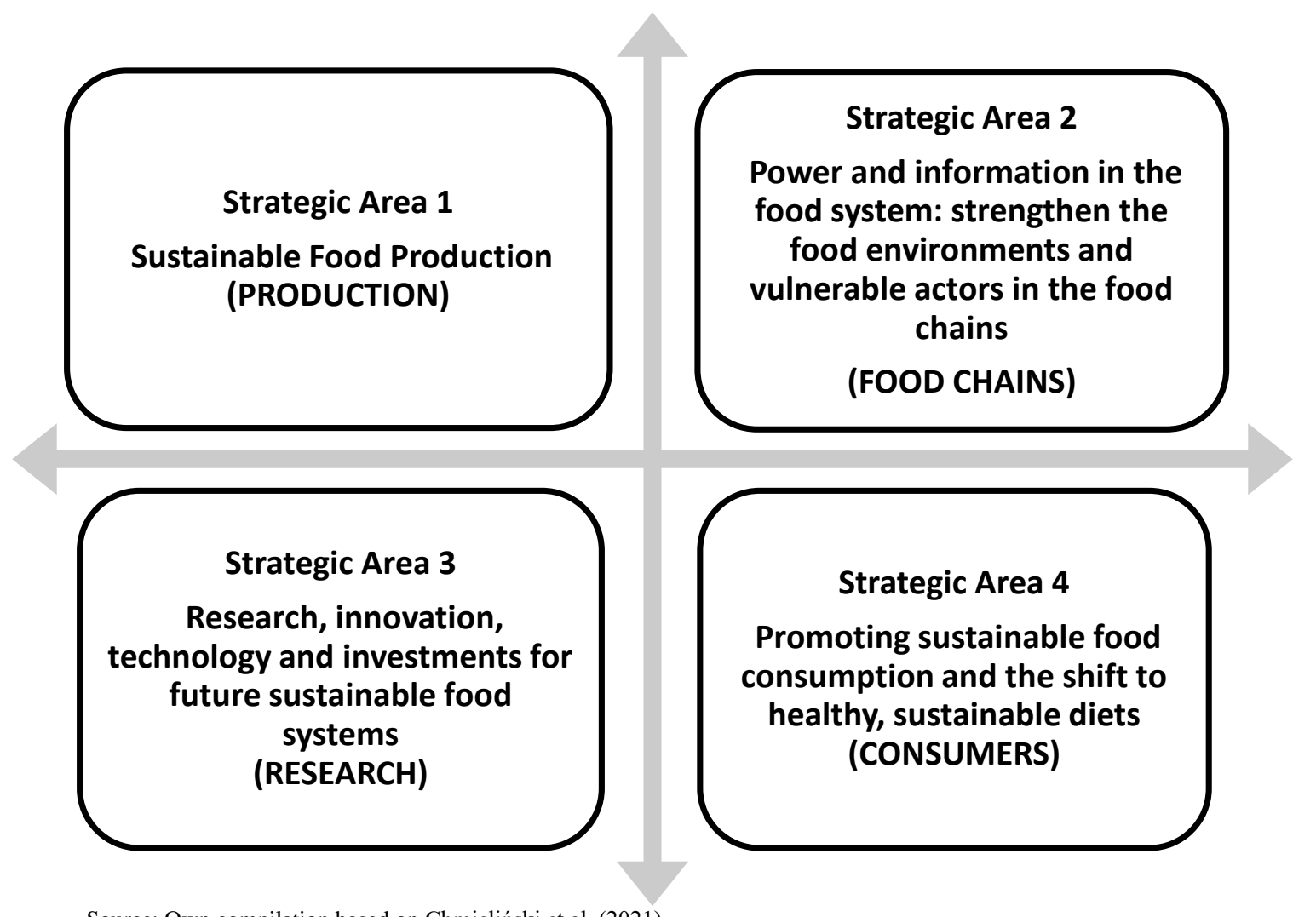

Source: Own compilation based on Chmieliński et al. (2021)

Figure 1. Strategic areas of the research and innovation for the sustainable food systems transformation in CEECs

\section{Sustainable Food Production}

The first of the identified impact areas for improving the organisation's livelihood systems is to support sustainable food production. This approach emphasises the need to ensure sustainable food production by human and financial investment in innovation, skills and technology shift. Fundamental transformations in the activities of agricultural producers require inputs that would change current agricultural production practices, stimulating reduction of use and risk and dependency on pesticides. This would enable better quality biomass to be used extensively in other sectors of the (bio)economy, from which the demand for new, biodegradable or biomass-based materials, such as the production and use of bioplastics, is increasingly strong. The new approach to the use of biomass, on the one hand, reduces its waste in primary production and, on the other hand, allows for the gradual elimination of materials that are currently at the heart of the problem with rubbish and its management.

For primary production, a need has been identified to optimise the harvest for the applied processing technologies and reduce food waste by finding the best use of the raw materials and by-products. This is relevant not only at the level of one farm but also along the chain, where due to the complex organizational structure, the process of the efficient management of food flows and handling is a big challenge. Excessive quantities of products in the market as well as longer distribution and logistics channels result in the increasing losses and waste of food worldwide. This phenomenon is observed at all the stages of the food supply chain "from field to table", starting from the primary production, through processing, sale, catering, distribution, down to households, that is confirmed by Bilska et al. (2016).

\section{Power and information in the food system: strengthen the food environments and vulnerable actors in the food chains}

Another issue of food systems development is power and information, i.e. strengthen the food environments and vulnerable actors in the food chain. The relations between its actors and the power they represent in the fair distribution of benefits, makes the third area is research and development challenges. It means also promoting sustainable short food chains, organic farming, initiatives and new green business models in food processing, wholesale, retail and food services, what is line with the recent studies (Chmielinski et al., 2019; Jolink \& Niesten, 2015). To this end, institutional changes are required to educate effective systems to tackle food fraud along the food supply chain (Montanari et al., 2016), as well as development of information hubs to connect primary producers with potential customers, see: (Bachev, 2020). 
Research, innovation, technology and investments for future sustainable food systems

Another framework issue on the way towards sustainable food systems is the correct and modern organisation of science as a basis for good monitoring and support to policy planning. First of all, the need for a system of environmental, biodiversity and natural capital observation was identified, based on the search for new data to better describe changes in food chains as well as relations between actors, but also the growing role of values, beliefs and consumption patterns in society, which determine the demand for new products and services. This includes the need for advanced statistical techniques and food system dynamics modelling as well as risk management at global, EU, national and local level. Subsequently, the role of the research and innovation sector is to translate research results well towards application both in public administration and (above all) by producers, thus it is important to involve science more closely in the agricultural advisory system in order to enhance the competences of those who decide on the structure of production or on the techniques and means of production used. One of the key elements for improving the relationship between science and practice is to further support the development of digital techniques for acquiring research material, processing it and using the research results in practice. Digital technologies make it possible to create knowledge resources that can be widely disseminated, ensuring easy access, also from traditionally disadvantaged areas located marginally in relation to centres.

On the other hand, an essential role of science is to help a better understanding of planetary boundaries, to help understand the complex system of interrelationships between nature, human activities, food production, and their importance in culture and the organisation of social life, what in litrerature is stressed byWebb et al. (2020). A holistic and global approach is required to well define the goal we are aiming for as a society, scientists, administrations and all actors in the food chain.

\section{Promoting sustainable food consumption and the shift to healthy, sustainable diets}

The proposed approach pays great attention to promoting sustainable food consumption and the shift to healthy, sustainable diets. Actions to influence consumers (i.e. society) must be designed to seek a change in consumption patterns, greater awareness of the impact of diet on health, responsibility in terms of the quantity and quality of food consumed and smart household waste management (see Slorach et al. (2020)). These actions require the involvement of consumers in the whole process of transfomation of food systems, but also on the side of producers. In this context, there is a need for reformulation of processed food, including the setting of maximum levels for certain nutrients, monitoring framework for responsible business and marketing in the food supply chain (Hinrichs, 2000). This also includes revision of EU marketing standards for agricultural, fishery and aquaculture products to ensure the uptake and supply of sustainable products. In addition, a good educational framework for sustainable food use and the shift to sustainable diets (eg. new nutrient profiles to restrict promotion of food high in salt, sugars and fat) is needed. Changing consumer awareness and behaviour is a key driver of change in food systems, as consumers influence the structure of demand and are therefore most effective in changing the production profiles of companies (Chmieliński et al., 2021).

\section{CONCLUSIONS}

This paper presents the results of a participatory approach to identifying challenges facing food systems in Central and Eastern European countries, developed by a group of scientists and representatives of public administration and farm advisory services working within the thematic working group of the BIOEAST initiative. The period of work covered 2019-2021 during which the groupworked together to identify areas and research topics that could lead to policies to better exploit the potential of the research and innovation sector in CEE countries to support their transformation towards sustainable food systems.

These works led to distinguishing four main priority axes related to the need of joint actions of science and administration in the macroregion, related to sustainable food production, food chains, research infrastructure and consumer awareness.

Within these four strategic areas, specific research directions have been defined, inter alia related to the need to improve knowledge, skills of farmers, access to information and positioning in the supply chain, but also to support the development of scientific infrastructure, statistical bases and research methodologies for a better understanding of food systems, as well as activities to change consumer attitudes towards nutrition and more aware choices related to food, diet and responsible consumption, among others. These directions coincide with the recommendations arising from the analysis of literature on, inter alia, innovation, nutrition, consumption, sustainable rural development and agriculture. Around these axes, work is being carried out to create a research and innovation strategy, which would help to support both scientific research and better use of its results in the activities of the administration, following the principles of evidence-based policy making for sustainable food systems development in CEECs.

\section{REFERENCES}

1. APHA. 2007. Toward a Healthy Sustainable Food System.

2. Bachev, H. 2020. Diagnosis of the System for Sharing Knowledge, Innovation and Digitalization in Agriculture (AKIS) in Bulgaria. Journal of Integrated Marketing Communications and Digital Marketing, Vol. 1, pp. 1-17.

3. Bergold, J., Thomas, S. 2012. Participatory research methods: A methodological approach in motion. Historical Social Research/Historische Sozialforschung, pp. 191-222.

4. Bilska, B., Wrzosek, M., Kołożyn-Krajewska, D., Krajewski, K. 2016. Risk of food losses and potential of food recovery for social purposes. Waste Management, Vol. 52, pp. 269-277. https://doi.org/10.1016/j.wasman.2016.03.035 
5. Bojnec, Š., Fertő, I. 2009. Agro-food trade competitiveness of Central European and Balkan countries. Food Policy, Vol. 34(5), pp. 417-425. https://doi.org/10.1016/j.foodpol.2009.01.003

6. Bojnec, Š., Fertő, I. 2015. Are new EU member states catching up with older ones on global agri-food markets? Post-Communist Economies, Vol. 27(2), pp. 205-215. https://doi.org/10.1080/14631377.2015.1026690

7. Chmielinski, P., Pawlowska, A., Bocian, M., Osuch, D. 2019. The land is what matters: factors driving family farms to organic production in Poland. British Food Journal, Vol. 121(6), pp. 1354-1367. https://doi.org/10.1108/BFJ-05-2018-0338

8. Chmieliński, P. 2021. Analiza SWOT i mapa potrzeb badawczych w Polsce (SWOT analysis and mapping of research needs in Poland). Workshops of the National Co-operation Platform of the BIOEAST Initiative (18.02.2021), Warsaw (online).

9. Chmieliński, P., Wigier, M., Cieślikowska, J. 2021. Research and innovation in the food system transformation in BIOEAST countries. BIOEAST conference: "The role of Central and Eastern European countries in the context of European food systems research and innovation" Warsaw (online), 24.06.2021.

10. de Vries, H. 2021. Food science and technology contributes to sustainable food systems. Trends in Food Science \& Technology, Vol. 116, pp. 1200-1202. https://doi.org/10.1016/j.tifs.2021.05.026

11. EC. 2020. Towards a sustainable food system. Moving from food as a commodity to food as more of a common good: independent expert report. Publications Office of the European Union.

12. El Bilali, H. 2019. The multi-level perspective in research on sustainability transitions in agriculture and food systems: A systematic review. Agriculture, Vol. 9(4), 74. https://doi.org/10.3390/agriculture9040074

13. FAO. 2018. Sustainable food systems: concept and framework.

14. Galli, F., Favilli, E., D’Amico, S., Brunori, G. 2018. A transition towards sustainable food systems in Europe. Food Policy Blue Print Scoping Study. Laboratorio di Studi Rurali Sismondi: Pisa, Italy.

15. Giuntoli, J., Robert, N., Ronzon, T., Sanchez Lopez, J., Follador, M., Girardi, I., Barredo Cano, J., Borzacchiello, M., Sala, S., M'Barek, R. 2020. Building a monitoring system for the EU bioeconomy. Publications Office of the European Union: Luxembourg.

16. Hinrichs, C. C. 2000. Embeddedness and local food systems: notes on two types of direct agricultural market. Journal of Rural Studies, Vol. 16(3), pp. 295-303. https://doi.org/10.1016/S0743-0167(99)00063-7

17. Horváth, K. 2019. Hidden opportunities but urgent problems - The economic potential of the Visegrad Cooperation and Fund. PEFnet - Book of Abstracts, 2019, Brno, The Czech Republic.

18. Jolink, A., Niesten, E. 2015. Sustainable development and business models of entrepreneurs in the organic food industry. Business Strategy and the Environment, Vol. 24(6), pp. 386-401. https://doi.org/10.1002/bse.1826

19. Juhász, A., Vásáry, V. 2017. BioEast: Central-Eastern European initiative for knowledge-based agriculture, aquaculture and forestry in the bioeconomy. Rural Areas and Development, Vol. 14, pp. 75-91. https://doi.org/10.7896/e.1046

20. Kneafsey, M., Venn, L., Schmutz, U., Balázs, B., Trenchard, L., Eyden-Wood, T., Bos, E., Sutton, G., Blackett, M. 2013. Short food supply chains and local food systems in the EU. A state of play of their socio-economic characteristics. JRC Scientific and Policy Reports, Vol. 123, 129.

21. Lang, T. 2003. Food industrialisation and food power: implications for food governance. Development Policy Review, Vol. 21(5-6), pp. 555-568. https://doi.org/10.1111/j.1467-8659.2003.00223.x

22. Montanari, F., Varallo, C., Pisanello, D. 2016. Food Fraud in the EU. European Journal of Risk Regulation, Vol. 7(1), pp. 197-205. https://doi.org/10.1017/S1867299X0000550X

23. Moote, M. A., McClaran, M. P., Chickering, D. K. 1997. Theory in practice: Applying participatory democracy theory to public land planning. Environmental Management, Vol. 21(6), pp. 877-889. https://doi.org/10.1007/s002679900074

24. Niels, H., Henk, W. 2019. The added value of a Food Systems Approach in Research and Innovation. Policy Brief by Standing Committee on Agricultural Research (SCAR) Strategic Working Group on Food Systems. Publications Office of the European Union.

25. Potori, N., Chmieliński, P., Fieldsend, A. 2014. Structural changes in Polish and Hungarian agriculture since EU accession: Lessons learned and implications for the design of future agricultural policies. Agrárgazdasági Kutató Intézet.

26. Sautier, M., Piquet, M., Duru, M., Martin-Clouaire, R. 2017. Exploring adaptations to climate change with stakeholders: A participatory method to design grassland-based farming systems. Journal of Environmental Management, Vol. 193, pp. 541-550. https://doi.org/10.1016/j.jenvman.2017.02.050

27. SCAR. 2018. Assessment of Research and Innovation on Food Systems by European Member States. Publications Office of the European Union.

28. Slorach, P. C., Jeswani, H. K., Cuéllar-Franca, R., Azapagic, A. 2020. Assessing the economic and environmental sustainability of household food waste management in the UK: Current situation and future scenarios. Science of The Total Environment, Vol. 710, 135580. https://doi.org/10.1016/j.scitotenv.2019.135580

29. Sonnino, R., Callenius, C., Lähteenmäki, L., Breda, J., Cahill, J., Caron, P., Damianova, Z., Gurinovic, M., Lang, T., Lapperière, A. 2020. Research and Innovation Supporting the Farm to Fork Strategy of the European Commission. Policy brief 3. European Union.

30. Vásáry, V. 2019. Knowledge-based agriculture in Central and Eastern European Countries' bioeconomy. Economic and Environmental Studies, Vol. 19, No. 1(49/2019), pp. 137-154.

31. Webb, P., Benton, T. G., Beddington, J., Flynn, D., Kelly, N. M., Thomas, S. M. 2020. The urgency of food system transformation is now irrefutable. Nature Food, Vol. 1(10), pp. 584-585. https://doi.org/10.1038/s43016-020-00161-0

32. Wrzaszcz, W., Zegar, J. S., Prandecki, K. 2015. Soil fertility and economic efficiency-the case of Polish agriculture. Bulgarian Journal of Agricultural Science, Vol. 21(1), pp. 467-478.

33. Zegar, J. S. 2021. Long-term strategy for sustainable development of agriculture in Poland. Zagadnienia Ekonomiki Rolnej, Vol. 367(2), pp. 16-30. https://doi.org/10.30858/zer/138346 